\title{
Ankaferd-Induced Early Soft Tissue Wound Healing in an Experimental Rat Model
}

\author{
Deneysel Rat Modelinde Ankaferd ile \\ İndüklenmiș Erken Dönem Yumuşak Doku \\ İyileşmesi
}

\author{
Alper AKTAŞ, ${ }^{a}$ \\ Nuray ER, ${ }^{a}$ \\ Petek KORKUSUZ, \\ Dilara ZEYBEK, ${ }^{b}$ \\ Mehmet Ali ONUR, ${ }^{\circ}$ \\ Gamze TAN, ${ }^{\circ}$ \\ Oktay ÖZDEMIR, ${ }^{\mathrm{d}}$ \\ Eda KARAISMAILOĞLU, ${ }^{e}$ \\ Erdem KARABULUTe

\section{aDepartment of} \\ Oral Maxillofacial Surgery, \\ Hacettepe University Faculty of Dentistry, \\ Departments of \\ ${ }^{b}$ Histology and Embryology, \\ eBiostatistics, \\ Hacettepe University Faculty of Medicine \\ 'Department of Biology, \\ Hacettepe University Faculty of Science, \\ Ankara \\ APrivate, İstanbul
}

Geliş Tarihi/Received: 29.06 .2012

Kabul Tarihi/Accepted: 18.05 .2013

Yazışma Adresi/Correspondence: Alper AKTAS

Hacettepe University Faculty of Dentistry, Department of Oral Maxillofacial Surgery, Ankara,

TÜRKIYE/TURKEY

alperaktas@gmail.com

\begin{abstract}
Objective: Ankaferd blood stopper (ABS) is a unique standardized medicinal plant extract which has been approved in the management of post-surgical external bleeding and dental surgery in Turkey. ABS is obtained from five different plants' extracts namely Thymus vulgaris, Glycyrrhiza glabra, Vitis vinifera, Alpinia officinarum and Urtica dioica. The aim of this paper is to test the effects and search the underlying molecular mechanisms of ABS on the early wound healing process of extraction socket's soft tissue in a rat experimental model. Material and Methods: Locally bred female 20 albino rats' right and left maxillary molars were extracted. On the right side, $0.2 \mathrm{~mL}$ ABS was applied on each socket, and the left side was used as the control. The animals were sacrificed on 1,2,4 and $7^{\text {th }}$ days. Indirect immunohistological procedure was performed on cryosections. Digital images were captured and quantitative image analysis was carried out for various immunohistochemical markers; collagen type 1 , collagen type 3 , $\alpha$-smooth muscle actin, fibronectin, $\beta 2$ microglobulin, vascular endothelial growth factor and, cyclooxygenase-2. Results: Immune reactivity was augmented statistically significantly $(\mathrm{p}<0.05)$ in various days for; collagen type 1 , collagen type 3, $\alpha$-smooth muscle actin, fibronectin, $\beta 2$ microglobulin, vascular endothelial growth factor, Cyclooxygenase- 2 and mononuclear phagocyte marker. Conclusion: ABS enhanced the number of the cells harboring the important markers of soft tissue healing as well as the biological reactivity of these cells for these molecules in the extraction sockets. Therefore this study is important for evaluating wound healing accelerating effect of ABS.
\end{abstract}

Key Words: Wound healing; models, animal; immunohistochemistry; Ankaferd blood stopper

ÖZET Amaç: Ankaferd Blood Stopper (ABS) ${ }^{\circledR}$, Türkiye'de eksternal kanamalarda kullanılmak üzere onay almış bitki kökenli bir ekstrakttır. ABS, Thymus vulgaris, Glycyrrhiza glabra, Vitis vinifera, Alpinia officinarum ve Urtica dioica isimli beş bitkinin ekstraktından elde edilmektedir. Bu çalışmanın amacı deneysel rat modelinde ABS'nin çekim bölgesindeki yumuşak doku yara iyileşmesi üzerine olan etkinliğinin ve bunun mekanizmasının erken safhada değerlendirilmesidir. Gereç ve Yöntemler: Standart yem ile beslenmiş 20 dişi albino ratın sağ ve sol maksiller molarları çekildi. Sağ tarafta çekim sonrası boş kalan her sokete $0,2 \mathrm{~mL}$ ABS uygulandı, sol taraf kontrol grubu olarak bırakıldı. Ratlar 1,2,4 ve 7. günlerde sakrifiye edildi. Kryokesitler üzerinde yara iyileşmesinde görev alan kollajen tip 1, kollajen tip 3, $\alpha$-düz kas aktin, fibronektin, $\beta 2$ mikroglobulin, vasküler endotelyal büyüme faktörü ve siklooksijenaz-2 indirekt immünohistokimyasal yöntemlerle işaretlenerek, elde edilen veriler üzerinden sayısal analiz yapıldı. Bulgular: Kollajen tip 1, kollajen tip 3, $\alpha$-düz kas aktin, fibronektin, $\beta 2$ mikroglobulin, vasküler endotelyal büyüme faktörü, siklooksijenaz-2 ve tek çekirdekli fagosit immün işaretlenme skorları için elde edilen sonuçlar, çeșitli günlerde istatistiksel olarak anlamlı derecede arttı $(p<0,005)$. Sonuç: ABS, çekim soketinde yumuşak doku iyileşmesinin önemli belirteçlerini barındıran hücrelerin sayısını ve bu moleküller açısından biyolojik aktivitesini arttırmaktadır. Bu nedenle çalışma, ABS'nin yara iyileşmesini erken dönemde hızlandırıcı etkisinin değerlendirilmesi açısından önemlidir.

Anahtar Kelimeler: Yara iyileşmesi; modeller,hayvan; immünohistokimya; Ankaferd kan durdurucu 
enerally, wound healing involves the following events: rapid hemostasis, appropriate inflammation, mesenchymal cell differentiation, proliferation, and migration to the wound site, suitable angiogenesis, prompt re-epithelialization (re-growth of epithelial tissue over the wound surface), and proper synthesis, crosslinking, and alignment of collagen to provide strength to the healing tissue. ${ }^{1-3}$

Non-healing wounds affect about 3 to 6 million people in the United States, with persons 65 years and older accounting for $85 \%$ of these events. Non-healing wounds result in enormous health care expenditures, with the total cost estimated being more than $\$ 3$ billion per year. ${ }^{3,4}$ There are several systemic and local conditions that affect tooth extraction socket healing: difficult or traumatic extraction, use of oral contraceptives, tobacco use, old age, uncontrolled diabetes, immunocompromised patients, radiation therapy, chemotherapy, biphosphonate therapy and malnutrition are some examples of predisposing factors for delayed or non-healed extraction sockets. ${ }^{5-9}$ Therefore, there are numerous studies in the literature about accelerating the healing rate of wounds. ${ }^{10,11} \mathrm{ABS}$ can be a new agent to be used in wound healing acceleration owing to its easy application and hemostatic effect. Therefore, this study is crucial for evaluating ABS's wound healing accelerating effect.

Using hemostatic materials carries a risk of infection and may delay healing, therefore they should be avoided in immune suppressed patients. ${ }^{12}$ Mattsson et al. showed that hemostatic agents Astroplast and Hemastogen provoked adverse tissue reactions including foreign body giant cell formation more than bone wax. ${ }^{13}$ Matthew et al. investigated the healing effect of non-wowen sodium calcium alginate fibers and oxidized regenerated cellulose over tooth extraction sockets. ${ }^{14}$ They showed that both biomaterials delayed wound healing in the early phase, giving rise to foreign body reactions. There are numerous bleeding disorders in dental patients which may also be accompanied with immune suppression, therefore an agent which has both hemostatic and wound healing accelerator properties may posses great advan- tages to be used in these patients. ${ }^{12} \mathrm{ABS}$ seems to be a good candidate to have these properties. Besides, this study is the first study that uses a hemostatic agent as an experimental tool for determining the healing effect in the extraction socket.

Ankaferd blood stopper ${ }^{\circledR}$ (ABS) is a standardized herbal extract, which has been approved in the management of post-surgical external bleeding and dental surgery in Turkey. ${ }^{15}$ ABS is obtained from five different plants namely Thymus vulgaris, Glycyrrhiza glabra, Vitis vinifera, Alpinia officinarum and Urtica dioica. ABS, as a topical hemostatic agent, has been approved for the clinical management of bleeding. ${ }^{15}$ ABS Phase III studies were performed in vascular port insertion bleeding, anterior epistaxis, oral cavity bleedings of children with hemorrhagic diathesis, various dental procedures and post-tonsillectomy hemorrhages. ${ }^{16-19}$ The basic mechanism of action for ABS is the formation of an encapsulated protein network that provides focal attachment points for very rapid ( $<1 \mathrm{sec})$ vital erythrocyte aggregation. ABS-induced protein network with blood cells, particularly erythrocytes, covers the primary and secondary hemostatic system without disturbing individual coagulation factors. ${ }^{15,20,21}$ Besides its hemostatic activity, ABS may also inhibit the growth of bacteria. ${ }^{22}$ The wound healing effect of ABS was briefly investigated by Gul et al. ${ }^{23}$ In this study, ABS's mechanism of action was not reported, but the beneficial effect of the drug was mentioned for bone healing.

The aim of this paper was to test the effects of ABS on the early soft tissue wound healing process in a rat extraction socket experimental model. In order to determine the effect of ABS on early soft tissue healing process, the immunohistochemical markers related to the molecules and extracellular matrix (ECM) components having roles during healing procedure; [collagen type 1, collagen type $3, \alpha$-smooth muscle actin ( $\alpha$-SMA), fibronectin $(\mathrm{FN}), \beta$-2-microglobulin $(\beta 2 \mathrm{M})$, vascular endothelial growth factor (VEGF), cyclooxygenase-2 (COX-2) and mononuclear phagocyte marker] were assessed. Elucidation of the exact's 'mechanism of action' as "ABS-induced wound healing" may expand its clinical usage. 


\section{MATERIAL AND METHODS}

\section{ANIMAL MODEL}

Twenty locally bred female albino rats (Rattus norvegicus) weighing 300-340 g were used in the present study. The experimental protocol for the use of animals was approved by the Institutional Animal Care Committee (B.30.2.HAC.0.01.00. $05 / 120)$. Rats were randomly assigned into 4 groups $(\mathrm{n}=5)$ according to sacrificing period $\left(1,2,4\right.$ and $7^{\text {th }}$ days). Rats were anesthetized with a mixture of xylazine (Rompun, 2\% solution, Bayer, Germany) and ketamine hydrochloride (Ketalar, $30 \mathrm{mg} / \mathrm{kg}$, Parke Davis, Turkey). The ratio of xylazine and ketamine hydrochloride in the mixture was 3:1. Right and left maxillary molars were extracted. On the right side, ABS was applied at a dose of $0.2 \mathrm{~mL}$ on each socket, and the left side was used as the control. Extraction sites were not sutured. The maxillae of the animals were removed with the attached gingival tissue, and separated into two pieces as the control and the ABS site.

\section{IMMUNOHISTOLOGICAL EVALUATION}

For histology and immunohistology, fresh gingival samples were surgically removed, immediately frozen in liquid nitrogen, and kept in it until cryostat sectioning. Conventional histological examination was performed on 6-8 micrometer-thick cryo-sections that were stained with methylene blue to evaluate wound site prior to immune labeling. Immunohistological procedure used in this study was described in detail previously. ${ }^{24,25}$ In brief, 6-8 micrometer thick sections on poly-Llysine coated slides were fixed in acetone, and airdried. Anti-mouse, anti-rabbit and anti-goat HRP-DAB staining kit (Table 1) was used according to manufacturers' protocol. Unspecific binding was blocked by rat serum. Sections were incubated in a humidified chamber for an hour with monoclonal antibodies, which are listed in Table 1. After washing in $0.01 \mathrm{M}$ phosphate buffered saline (PBS) at $\mathrm{pH} 7.4$, the sections were incubated with biotinylated anti-mouse, anti-rabbit or anti-goat secondary antibodies. After rinsing in PBS, slides were covered with HSS-HRP for 30 minutes at the room temperature. The sections were washed with PBS, and incubated with 3.3'-diaminobenzidinetetrahydrochloride (DAB) for 2 minutes according to suppliers' written steps. After washing with tap water, sections were stained with Mayer's hematoxylin and dehydrated through graded alcohols and cleared in xylene prior to mounting with entellan (Merck, Germany). All antibodies were diluted in a background reducing buffer solution in $0.05 \mathrm{M}$ TrisHCl containing $0.1 \%$ tween 20 (\#S3022, Dako, USA). Negative control staining was performed by omitting the initial primary antibody staining step and using a control mouse Ig G. Positive control staining was performed by using appropriate control tissue samples provided by the manufacturer. All sections were examined and the digital images were captured by using Leica DM6000B microscope with a DC490 digital camera (Leica, Wetzlar-Germany). Quantitative image analysis was carried out for collagen type 1, colla-

\begin{tabular}{|lccccc|}
\hline \multicolumn{7}{c}{ TABLE 1: } & Antibodies that are used for wound healing study. \\
\hline Antibody & Clone & Isotype & Catalog Number & Source & Dilution \\
Collagen1 & na & Polyclonal lgG & $2150-1908$ & AbD Serotec & $1: 20$ \\
Collagen III & na & Polyclonal lgG & $2150-1950$ & AbD Serotec & $1: 250$ \\
$\alpha$-SMA & AA4 & Mouse lgG2a & MCA 1905 & AbD Serotec & $1: 20$ \\
B2M & TLD-3H12B & Mouse lgG1 & MCA1740 & AbD Serotec & $1: 10$ \\
FN & EP5 & Mouse lgG1 & SC-8422 & Santa Cruz & $1: 10$ \\
Cox-2 & N-20 & Goat lgG & Sc-1746 & Santa Cruz & $1: 10$ \\
VEGF & NSO- & Goat lgG & AF564 & R\&D Syst. & $1: 10$ \\
Mononuclear phagocyte & $1 C 7$ & Mouse lgG1, $\mp$ & 550305 & BD Pharmingen & $1: 20$ \\
\hline
\end{tabular}

$\alpha$-SMA: $\alpha$-smooth muscle actin; $\beta 2 \mathrm{M}$ : $\beta$-2-microglobulin; FN: Fibronectin; COX-2: Cyclooxygenase-2; VEGF: Vascular endothelial growth factor. 
gen type 3 , $\alpha$-SMA, FN, $\beta 2 \mathrm{M}$, VEGF, COX-2 and mononuclear phagocyte marker immunoreactivity by using Leica Application Suit and Qwin Plus computer image analysis system (Germany) after modifying the technique in the literature. $.^{24,25} \mathrm{Max}-$ imum staining intensity was determined from the positive control tissue sections by using the image analysis system. Accordingly, each section was graded for cellular immune reaction on a scale of 0 to +++ with DAB. 0 was given to no immune reactivity, + to weak but continuous reactivity, ++ for moderate but continuous reactivity and +++ to intense but continuous immune staining. The number of i-positive cells was expressed as a percentage of positive cells over total cells at 200x magnification. In every specimen, the average of screened 3 non-overlapping fields was reported. Staining intensity was combined with the percentage of stained cells by using the HSCORE that was calculated with the following equation: $\mathrm{H}$ score $=\Sigma \rho$ $(i+1)$, where $i=$ intensity of staining with a value of (1 for + ), ( 2 for ++$)$ or (3 for +++$)$ and $\rho$ is the percentage of positive cells stained with each intensity (varying between $0-100$ ). $\Sigma$ :The sum of stained cells at different intensities.

\section{STATISTICAL ANALYSIS}

The normality of distribution was analyzed using the Shapiro-Wilk test. Since the normal distribution assumption was not satisfied, the immunohistologic data were analyzed using nonparametric tests. Descriptive statistics were expressed as median, minimum and maximum. Kruskal Wallis test was used for comparison of 4 groups according to sacrificing period (1, 2, 4 and $7^{\text {th }}$ days) and Dunn test was used as the post-hoc test. Wilcoxon signed ranks test was used to compare the ABS and control group (right and left side of the maxilla, respectively) on each sacrificing time. $\mathrm{p}<0.05$ was considered as statistically significant.

\section{RESULTS}

Collagen type 1 exhibited a strong and diffuse distribution pattern within the matrix of the hard and soft tissues from day 1 to day 7 in both control and ABS groups. On day 1 , immediately after tooth extraction, collagen type 1 immune reactivity was mostly observed at the deeper mucosa adjacent to the extraction sites. From day 4 to 7 , it shifted to the upper portion, into the granulation tissue. The immune reactivity of collagen type 1 was significantly increased in both groups in time until day 7 ( $\mathrm{p}_{\text {control }}=0.08$, $\mathrm{p}_{\mathrm{ABS}}=0.001$ ). Collagen type 1 scores were significantly lower in ABS group compared to the control group on day $1\left(\mathrm{p}_{1}=0.043\right)$ (Figures 1,2$)$ (Table 2).

Collagen type 3 showed a uniform distribution pattern at the base of the socket, on the periosteal surface, from day 1 to 7 in both groups. The granulation tissue exhibited a significantly increasing immune reaction for collagen type 3 in time for control group until seventh day $\left(\mathrm{p}_{\text {control }}=0.03\right)$. Collagen type 3 scores were significantly higher in ABS group compared to the control group on days 1,2 and 4 after tooth extraction $\left(\mathrm{p}_{1,2}=0.043\right.$, $\mathrm{p}_{4}=0,042$ ) (Figures 1, 2) (Table 2).

$\alpha$-SMA immune reactivity was significantly higher in ABS group compared to the control on days 2 and $7\left(p_{2,7}=0.043\right)$. Few fibroblastic cells expressed $\alpha$-SMA on the first day, after tooth extraction. The $\mathrm{H}$ scores significantly increased in time until day $7\left(\mathrm{p}_{\text {control }}=0.002, \mathrm{p}_{\mathrm{ABS}}=0.001\right)$. (Figure 2 , 3) (Table 2).

From the first day after tooth extraction, FN was widely expressed within the socket, and connective tissue matrix where collagen has been degraded. The provisional matrix consisted of fibrin and the newly forming granular collagen fibers at the initial phase of healing. This matrix strongly expressed FN from day 1 to 4 . The FN immune reaction was significantly higher in ABS group at all days when compared to the control group $\left(\mathrm{p}_{1,2,4,7}=0.043\right)$ (Figures 2, 3) (Table 2).

$\beta 2 \mathrm{M}$, as component of major histocompatibility complex class 1 (MHC 1) molecule, was expressed by several mononuclear cells within the granulation tissue; and the scores significantly increased in time in both groups $\left(\mathrm{p}_{\text {control }}=0.003\right.$, $\left.\mathrm{p}_{\mathrm{ABS}}=0.039\right) . \beta 2 \mathrm{M}$ immune reactivity augmented with ABS on days 1, 2 and 4 when compared to the control group $\left(\mathrm{p}_{1,2,4}=0.043\right)$ (Figures 2,4 ) (Table 2). 


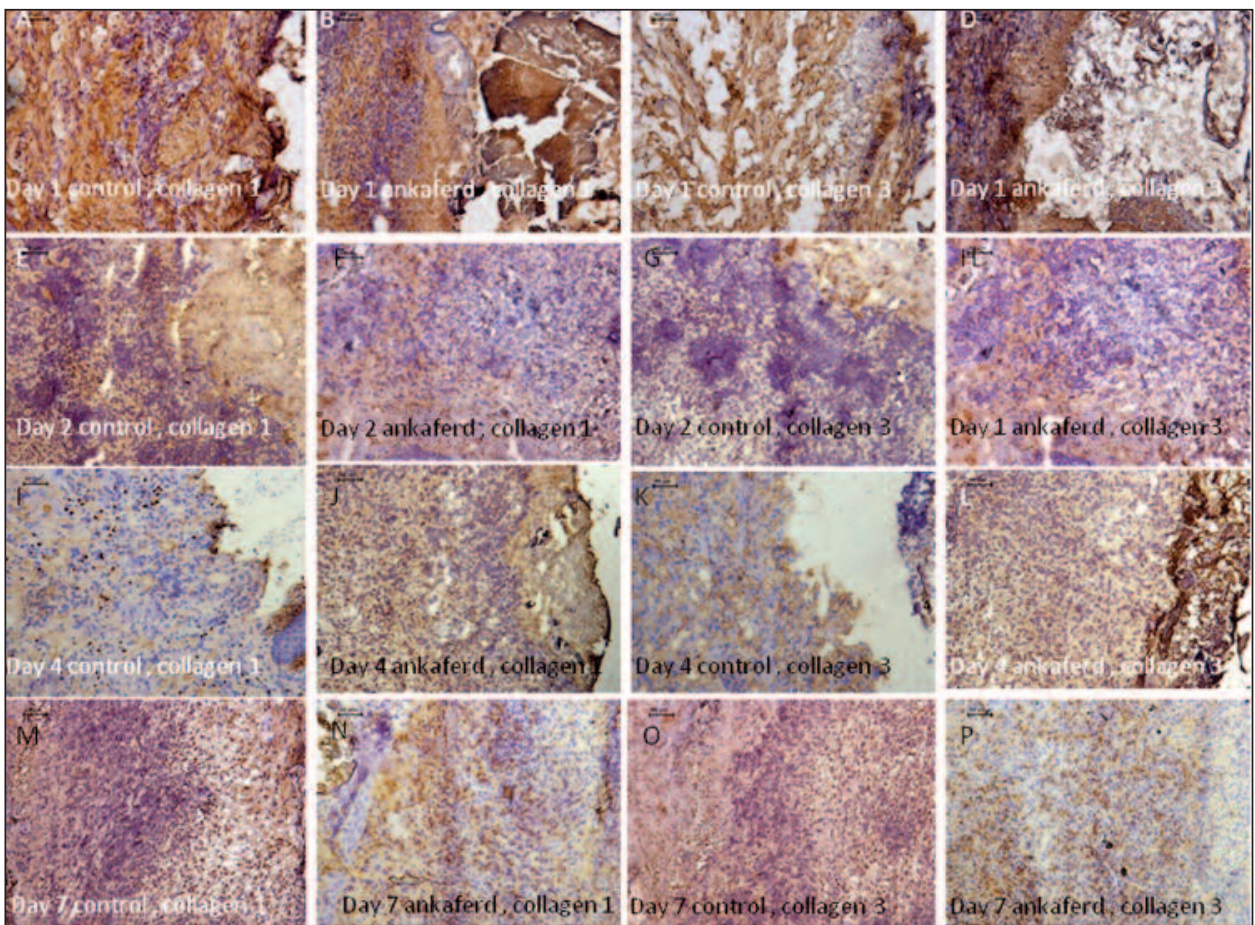

FIGURE 1: The first, second, third and the fourth rows show the micrographs of collagen type I and type III immunolabeled samples taken on days 1,2, 4 and 7. Brown cell and matrix elements are positively labeled with collagen type I or III, by using DAB as chromogen. The nuclei appear purple with hematoxylin (x200). (See color figure at http://www.turkiyeklinikleri.com/journal/tip-bilimleri-dergisi/1300-0292/)

Endothelial cells, some keratinocytes, platelets, polymorphonuclear leukocytes, macrophages and the fibroblasts expressed VEGF at different intensities within the granulation tissue. VEGF immune reaction was significantly augmented in $A B S$ group $\left(\mathrm{p}_{A B S}=0.023\right)$. The $H$ scores were significantly higher in ABS group when compared to the control group on days 2, 4 and 7 $\left(\mathrm{p}_{2,4,7}=0.043\right)$ (Figure 2, 4) (Table 2).

Mononuclear and some fibroblastic cells taking part in the granulation tissue expressed COX-2. The immune reactivity significantly augmented in time from day 1 to day 7 in ABS group ( $\mathrm{p}=0.014) . \mathrm{H}$ scores significantly increased in ABS group on day 2 when compared to the control group $\left(\mathrm{p}_{2}=0.043\right)$ (Figures 2, 5) (Table 2).

When mononuclear phagocyte marker is taken into account, immune reaction analysis revealed presence of increasing numbers of macrophages in time (from day 1 to day 7) in both the control and ABS groups ( $\mathrm{p}_{\text {control }}=0.001$, $\mathrm{p}_{\mathrm{ABS}}=0.001$ ). The granulation tissue invasion and macrophage infiltration were more prominent in

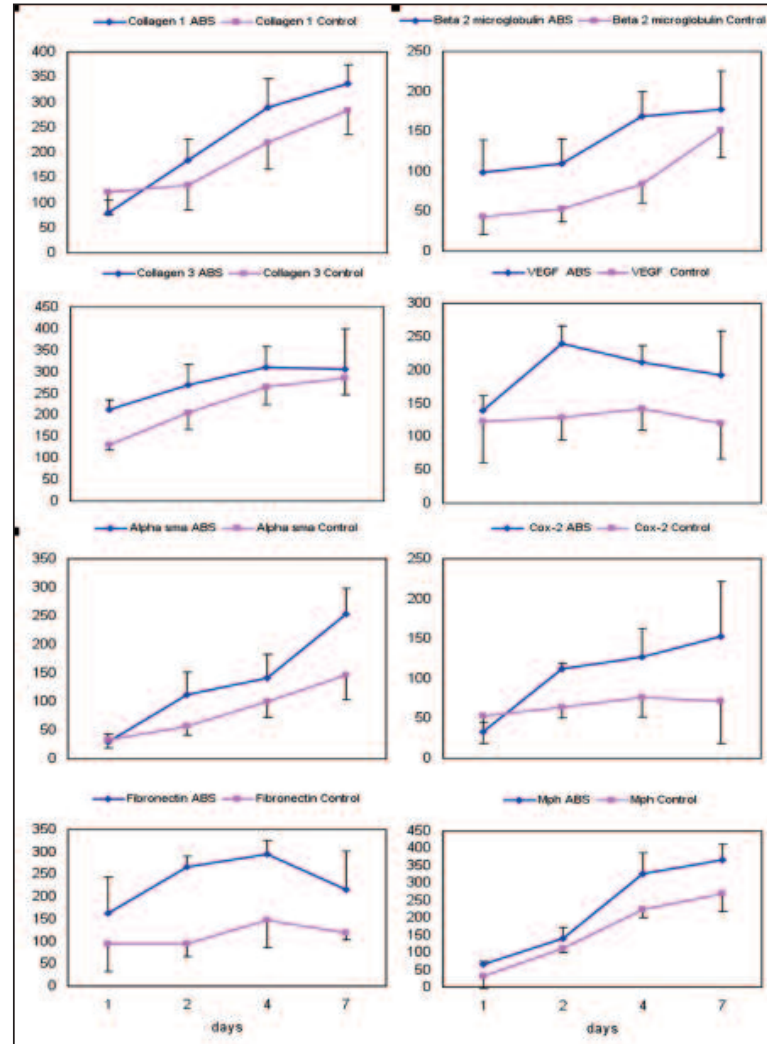

FIGURE 2: Median (minimum-maximum) values of immunohistochemical markers for control and ABS groups.

(See color figure at http://www.turkiyeklinikleri.com/journal/tip-bilimleri-dergisi/1300-0292/) 
TABLE 2: Median (minimum-maximum) and $p$ values of the control and ABS groups.

\begin{tabular}{|c|c|c|c|c|}
\hline & Day & $\begin{array}{c}\text { Control } \\
\text { Median (Min-Max) }\end{array}$ & $\begin{array}{c}\text { ABS } \\
\text { Median (Min-Max) }\end{array}$ & $p^{*}$ \\
\hline \multirow[t]{5}{*}{ Collagen 1} & 1 & $118(68-204)^{\mathrm{a}}$ & $82(46-112)^{a, b}$ & 0.043 \\
\hline & 2 & $128(74-210)$ & $198(122-244)$ & 0.345 \\
\hline & 4 & $220(146-304)$ & $304(204-376)^{a}$ & 0.068 \\
\hline & 7 & $290(204-346)^{\mathrm{a}}$ & $330(284-396)^{b}$ & 0.080 \\
\hline & $p$ & 0.008 & 0.001 & \\
\hline \multirow[t]{5}{*}{ Collagen 3} & 1 & $126(116-144)^{a, b}$ & $204(188-256)$ & 0.043 \\
\hline & 2 & $202(146-254)$ & $302(210-320)$ & 0.043 \\
\hline & 4 & $288(184-302)^{a}$ & $330(214-354)$ & 0.042 \\
\hline & 7 & $302(220-336)^{b}$ & 332 (124-386) & 0.686 \\
\hline & $p$ & 0.003 & 0.061 & \\
\hline \multirow[t]{5}{*}{$\alpha-S M A$} & 1 & $28(18-54)^{a}$ & $26(14-46)^{a}$ & 0.893 \\
\hline & 2 & $58(36-80)$ & $102(78-186)$ & 0.043 \\
\hline & 4 & $104(58-132)$ & $116(98-202)$ & 0.144 \\
\hline & 7 & $146(84-204)^{\mathrm{a}}$ & $242(196-336)^{a}$ & 0.043 \\
\hline & $p$ & 0.002 & 0.001 & \\
\hline \multirow[t]{5}{*}{ FN } & 1 & $84(34-210)$ & 146 (78-302) & 0.043 \\
\hline & 2 & $102(56-124)$ & 262 (232-302) & 0.043 \\
\hline & 4 & $124(58-234)$ & $302(256-332)$ & 0.043 \\
\hline & 7 & $114(98-142)$ & $186(122-338)$ & 0.043 \\
\hline & p & 0.289 & 0.124 & \\
\hline \multirow[t]{5}{*}{ B2M } & 1 & $36(22-84)^{a}$ & $112(34-142)$ & 0.043 \\
\hline & 2 & $46(38-84)^{b}$ & $112(68-159)$ & 0.043 \\
\hline & 4 & $84(52-116)$ & $184(110-194)$ & 0.043 \\
\hline & 7 & $134(112-204)^{a, b}$ & $156(124-258)$ & 0.345 \\
\hline & $p$ & 0.003 & 0.039 & \\
\hline \multirow[t]{5}{*}{ VEGF } & 1 & $94(54-204)$ & $146(108-168)^{a}$ & 0.500 \\
\hline & 2 & $132(68-176)$ & $226(204-278)$ & 0.043 \\
\hline & 4 & $134(106-203)$ & $196(188-258)$ & 0.043 \\
\hline & 7 & $94(56-204)$ & $168(96-288)^{a}$ & 0.043 \\
\hline & $p$ & 0.878 & 0.023 & \\
\hline \multirow[t]{5}{*}{ Cox-2 } & 1 & $34(18-104)$ & $36(16-54)^{a}$ & 0.686 \\
\hline & 2 & $64(46-84)$ & $112(104-124)$ & 0.043 \\
\hline & 4 & $82(32-102)$ & $112(86-174)$ & 0.080 \\
\hline & 7 & $64(16-174)$ & $184(54-224)^{a}$ & 0.138 \\
\hline & $p$ & 0.738 & 0.014 & \\
\hline \multirow[t]{5}{*}{$\mathrm{mph}$} & 1 & $30(16-48)^{a, b}$ & $67(26-112)^{a, b}$ & 0.043 \\
\hline & 2 & $104(68-165)$ & $174(36-204)^{c}$ & 0.343 \\
\hline & 4 & $236(118-306)^{a}$ & $334(274-382)^{a}$ & 0.043 \\
\hline & 7 & $273(210-336)^{b}$ & $368(346-382)^{b, c}$ & 0.043 \\
\hline & $p$ & 0.001 & 0.001 & \\
\hline
\end{tabular}

$\alpha$-SMA: $\alpha$-smooth muscle actin; $\beta 2 \mathrm{M}$ : $\beta$-2-microglobulin; FN: Fibronectin; COX-2: Cyclooxygenase-2; VEGF: Vascular endothelial growth factor; mph: Mononuclear phagocyte. $\mathrm{p}^{*}$ : $\mathrm{p}$ for Wilcoxon signed ranks test

$a, b, c:$ Same letter represents significant difference $(p<0.05)$ according to post-hoc Dunn test.
ABS group when compared to the controls by day 1, 4 and $7\left(\mathrm{p}_{1,4,7}=0.043\right)$ (Figures 2,5) (Table 2).

The descriptive statistics of the immunohistological analysis are given in Figure 2 and Table 2.

\section{DISCUSSION}

The early steps (clotting, inflammation, proliferation, maturation) of a surgical wound healing were observed histopathologically in this study (Figures 1,3-5). Statistically significant increases were determined in the reactivity of the immunohistochemical markers in the ABS group at various times when compared to the control group. Taking the increased reactivity of the immunohistochemical markers into consideration, ABS seems to accelerate early wound healing at the soft tissues.

The collagen family of proteins plays a dominant role in maintaining the integrity of various tissues. ${ }^{26}$ Type I collagen is the main protein in gingival tissue. Collagen plays an important role in connective tissue healing by providing tissue strength and an ECM framework for cell adhesion and migration. ${ }^{27}$ Both collagen type 1 and 3 increased in ABS group more compared to the control group especially in the deep portion of the sockets. However, the difference in collagen type 1 immune reactivity, which is mostly observed in the late time of tissue healing, was statistically significant only on day 1 and the amount decreased in ABS group. Besides, difference in immune reaction of collagen type 3 , which is produced quickly by young fibroblasts, was statistically significant. Increasing amount of collagen type 3 in ABS group may be considered as improved early healing phase of the wound. This situation may also increase the strength of the connective tissue which may speed up healing time. In order to assess the potential effect of ABS over collagen type 1 , long term studies should be done.

Smooth muscle cells and myofibroblasts share the expression of $\alpha$-SMA and its expression is frequently used to discriminate myofibroblasts from fibroblasts and protofibroblasts. ${ }^{26}$ This marker may also reflect the myofibroblast number in the wound area. Hinz et al. described these myofi- 


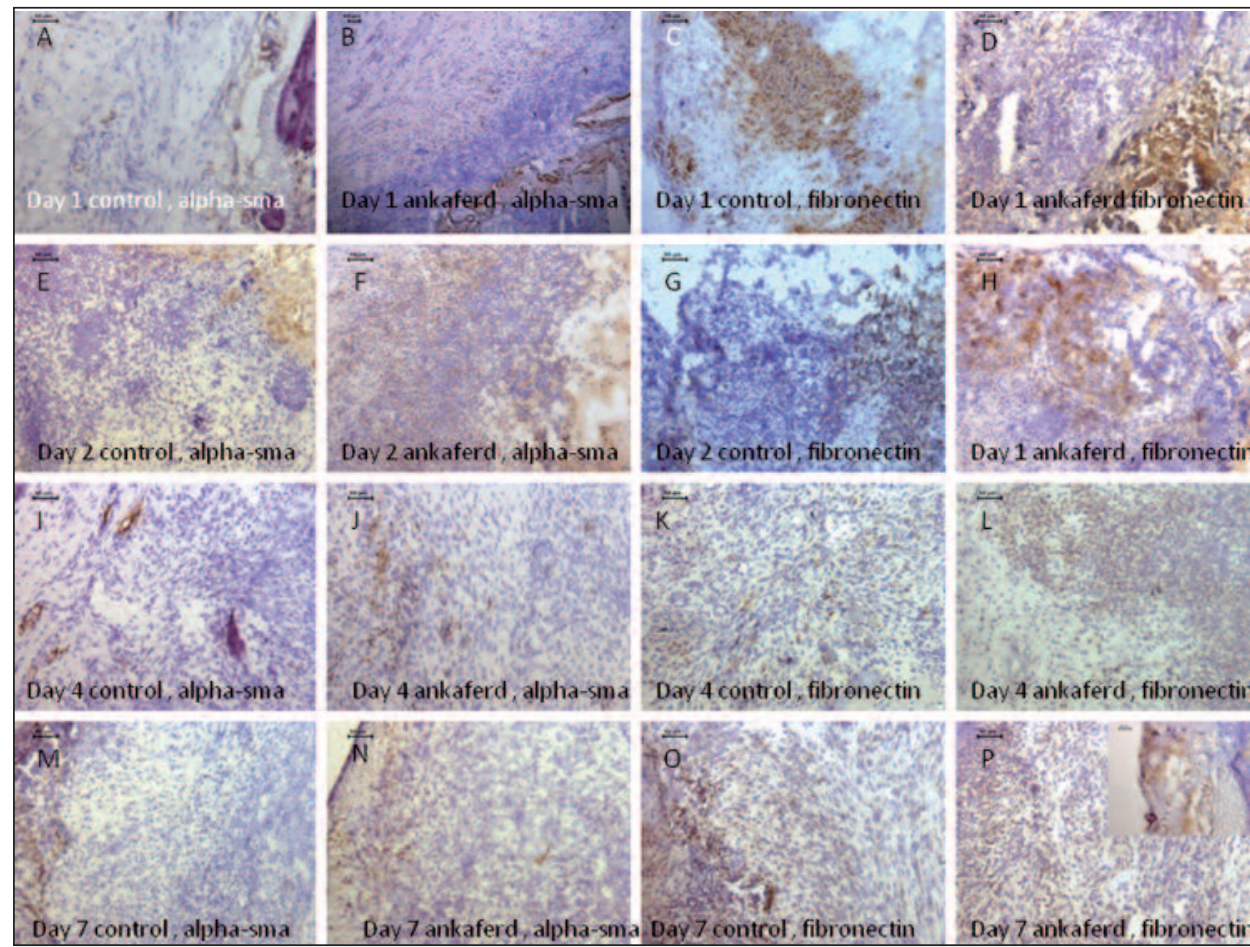

FIGURE 3: The first, second, third and the fourth rows show the micrographs of $\alpha$-SMA and FN immunolabeled samples on days 1, 2, 4 and 7. Brown cells/matrix elements are positively labeled with $\alpha$-SMA or FN, by using DAB as chromogen. The nuclei appear purple with hematoxylin. The P inset is the 400x magnified picture presenting the net-like blood stopper (x200).

(See color figure at http://www.turkiyeklinikleri.com/journal/tip-bilimleri-dergisi/1300-0292/)

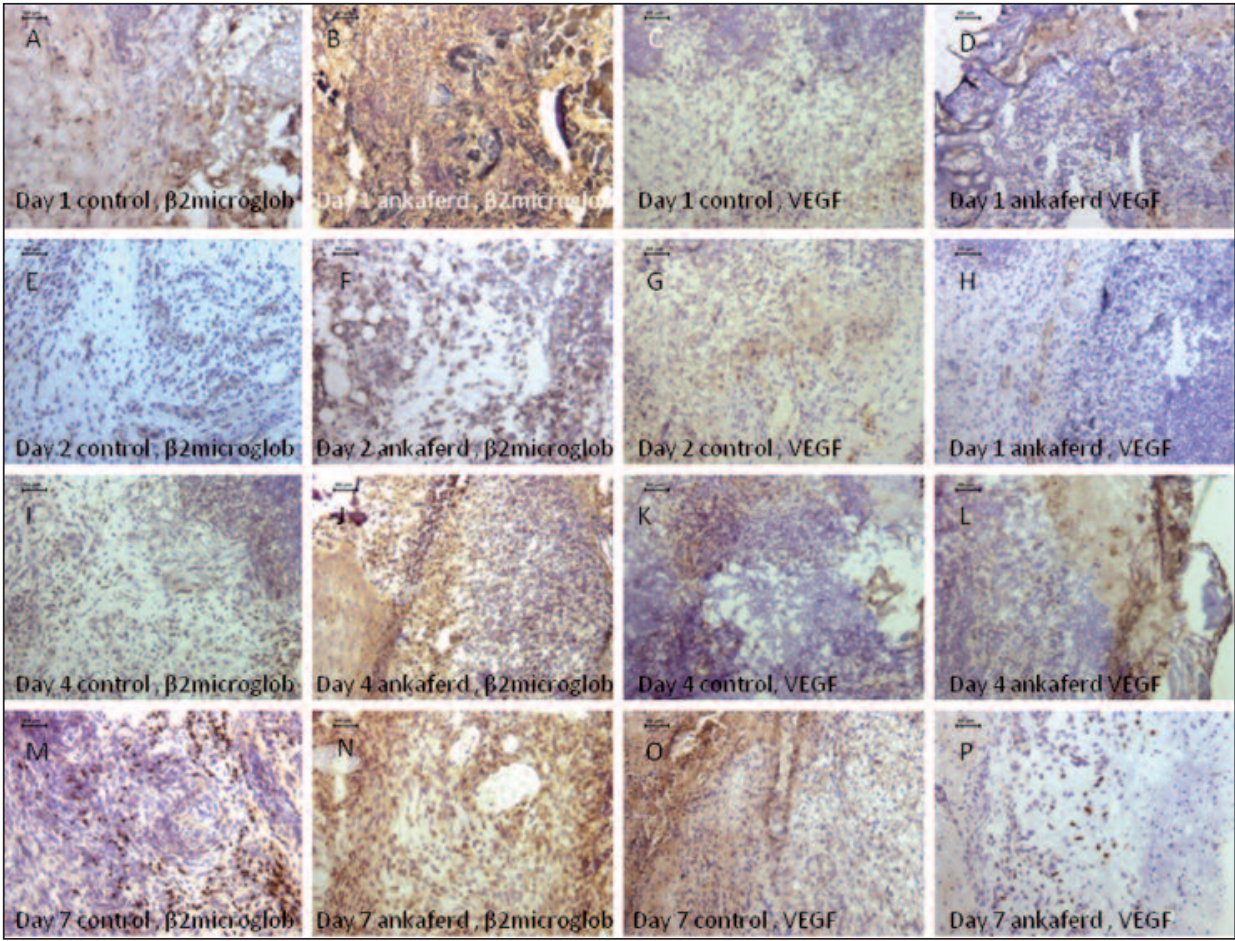

FIGURE 4: The first, second, third and the fourth rows show the micrographs of $\beta 2 \mathrm{M}$ and VEGF immunolabeled samples on days $1,2,4$ and 7 . Brown cells/matrix elements are positively labeled with $\beta 2 \mathrm{M}$ or VEGF, by using DAB as chromogen. The nuclei appear purple with hematoxylin (x200).

(See color figure at http://www.turkiyeklinikleri.com/journal/tip-bilimleri-dergisi/1300-0292/) 


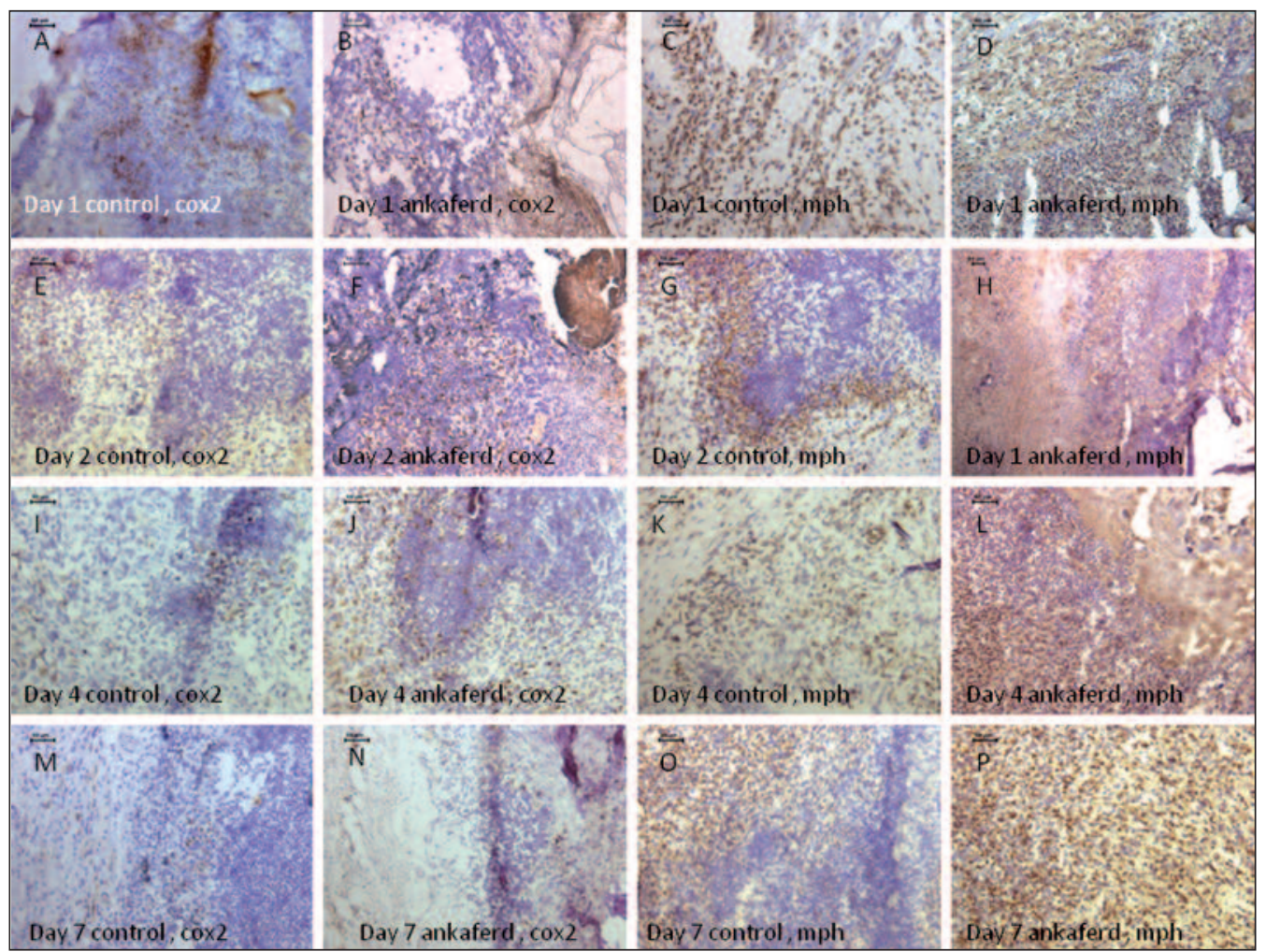

FIGURE 5: The first, second, third and the fourth rows show micrographs of COX 2 and mononuclear phagocytic marker immunolabeled samples on days 1,2, 4 and 7. Brown cells are positively labeled with COX 2 or mononuclear phagocytic marker, by using DAB as chromogen. The nuclei appear purple with hematoxylin. Note the increase of phagocytic cells inA-L and $\mathrm{P}(\mathrm{x} 200)$.

(See color figure at http://www.turkiyeklinikleri.com/journal/tip-bilimleri-dergisi/1300-0292/)

broblasts as the key factor in adult wound healing by mediating the deposition of ECM and its contraction during wound repair. ${ }^{28}$ Additionally it is known that, contraction of fibroblasts in certain connective tissues plays a critical role in the closure of skin wounds during healing. ${ }^{29-32}$ Statistically significant increase of $\alpha$-SMA in ABS group represents an accelerating action for wound healing, reflecting increased tissue contraction which results in decreased area of the wound. ABS effect over $\alpha-$ SMA separately may be the most important point for ABS' mode of action in accelerating the wound healing rate by decreasing the wound area.

During the repair and remodeling process, $\mathrm{FN}$ expression is upregulated, and locally produced cellular FN is a primary component of the granulation tissue that replaces the provisional matrix. FN matrix deposition and turnover are particularly dynamic at sites of tissue injury. ${ }^{33} \mathrm{FN}$ mediates a wide variety of cellular interactions with the ECM, and plays important roles in cell adhesion, migration, growth and differentiation. ${ }^{34,35}$ Hynes reported FN as an important ECM glycoprotein throughout wound repair. ${ }^{36} \mathrm{FN}$ was statistically significantly increased on all days $(1,2,4,7)$ when compared to the control group in the present study. This result can be an evidence for the ABS's accelerating effect on wound healing.

Ferrara indicated VEGF as an important growth factor, which played an important role in new blood vessel formation. ${ }^{37}$ There are studies about wound healing with or without VEGF. Rossiter et al. found delay of full-thickness skin wound healing in VEGF-deficient mice. ${ }^{38}$ Galiano et al. studied VEGF over diabetic wound healing and found that topical application of VEGF stimulated diabetic wound healing through increased angiogenesis. ${ }^{39}$ Statistically significant increase of VEGF in ABS group on days 2,4 and 7 demonstrates the early angiogenetic stimulatory effect of ABS. 
Increased new blood vessel formation will naturally ameliorate nutrition of the wound area.

$\beta 2 \mathrm{M}$ is a small (1 $2 \mathrm{kDa}$ ) polypeptide that is found in serum and, more importantly, in tight association with the MHC 1 heavy chain on the surface of nearly all nucleated cells. ${ }^{40}$ ABS group had a statistically significant increased $\beta 2 \mathrm{M}$ level on days 1,2 and 4 . This result can be evaluated as increased immune response for wound healing. This result must be evaluated in combination with the other immunohistological parameters which were used in this study for ABS using benefit in the wound healing process.

Macrophages appear to play an important role in orchestrating the repair process. The accumulation of activated macrophages into healing wounds results in enhanced wound repair, and activation of wound macrophages by either systemic or topical administration of the macrophage stimulants causes significantly increased wound-breaking strength. ${ }^{41,42}$ In the early phase of wound healing, macrophages release cytokines that promote the inflammatory response by recruiting and activating additional leukocytes. ${ }^{43}$ ABS group showed a statistically significant increase in macrophage number on days 1, 4 and 7. Increased amount of macrophages may indicate a possible mild tissue reaction for the ABS. When evaluated overall, the recruitment of the phagocytic cells into the granulation tissue in order to organize the tissue remodeling process affects the wound healing positively.

COX-2 is induced by cytokines in inflammatory cells such as macrophages and monocytes in tissue, at localized sites of injury. It is widely accepted that
COX-2 plays a key role in mediating pain and inflammation in response to tissue damage and in a variety of disease states. ${ }^{44} \mathrm{COX}-2$ acts in both the initiation of the inflammatory response and the resolution phase of inflammation. ${ }^{45}$ There are studies that are associated with delayed wound healing in COX-2 inhibited systems. ${ }^{46,47}$ Increased amount of COX-2 level in ABS group may indicate the increased inflammation. An important point is whether this inflammation rate will delay or accelerate the wound healing. Considering the above findings, ABS seems to increase the inflammatory response which may result in the quick resolution of inflammatory phase and increase of overall healing rate.

Based on the results of this immunohistological study, ABS enhanced the accumulation and biological actions of critical molecules representing the essential signals of early wound healing. Upregulated molecular responses associated with topical ABS administration can be ascribed to ABS-induced acceleration in the healing rate at the early phase of the complicated wound healing process. The wound healing ability of ABS, as concluded in this study, may open new avenues to expand its therapeutic potentials. In order to conclude ABS's effect over healing, long term studies showing complete soft and hard tissue healing should be accomplished.

\section{Acknowledgement}

We would like to thank Ibrahim C Haznedaroglu (MD) for valuable contribution on sharing his experience on Ankaferd.

\section{REFERENCES}

1. Gosain A, DiPietro LA. Aging and wound healing. World J Surg 2004;28(3):321-6.

2. Singer AJ, Clark RA. Cutaneous wound healing. N Engl J Med 1999;341(10):738-46.

3. Mathieu D. Linke JC, Wattel F. Non healing wounds. In: Mathieu D, ed. Handbook On Hyperbaric Medicine. $1^{\text {st }}$ ed. Dordrecht: Springer; 2006. p.401-27.
4. Menke NB, Ward KR, Witten TM, Bonchev $D G$, Diegelmann RF. Impaired wound healing. Clin Dermatol 2007;25(1):19-25.

5. Balaji S. Exodontia. Textbook of Oral Maxillofacial Surgery. $1^{\text {st }}$ ed. New Delhi: Elsevier; 2007. p. 211-27.

6. Shetty CB. Wound healing. In: Miloro M, ed. Peterson's Princibles of Oral Maxillofacial
Surgery. $2^{\text {nd }}$ ed. London: Hamilton; 2004. p.10-2.

7. Saia G, Blandamura S, Bettini G, Tronchet A, Totola A, Bedogni G, et al. Occurrence of bisphosphonate-related osteonecrosis of the jaw after surgical tooth extraction. J Oral Maxillofac Surg 2010;68(4):797804. 
8. Kobayashi Y, Hiraga T, Ueda A, Wang L, Matsumoto-Nakano M, Hata K, et al. Zoledronic acid delays wound healing of the tooth extraction socket, inhibits oral epithelial cell migration, and promotes proliferation and adhesion to hydroxyapatite of oral bacteria, without causing osteonecrosis of the jaw, in mice. J Bone Miner Metab 2010;28(2):165-75.

9. Devlin $\mathrm{H}$, Garland $\mathrm{H}$, Sloan $\mathrm{P}$. Healing of tooth extraction sockets in experimental diabetes mellitus. J Oral Maxillofac Surg 1996;54(9): 1087-91.

10. Jettanacheawchankit $S$, Sasithanasate $S$, Sangvanich P, Banlunara W, Thunyakitpisal $P$. Acemannan stimulates gingival fibroblast proliferation; expressions of keratinocyte growth factor-1, vascular endothelial growth factor, and type I collagen; and wound healing. J Pharmacol Sci 2009;109(4):525-31

11. Rutkowski JL, Johnson DA, Radio NM, Fennell JW. Platelet rich plasma to facilitate wound healing following tooth extraction. J Oral Implantol 2010;36(1):11-23.

12. Gupta A, Epstein JB, Cabay RJ. Bleeding disorders of importance in dental care and related patient management. J Can Dent Assoc 2007;73(1):77-83.

13. Mattsson T, Anderssén K, Koendell PA, Lindskog S. A longitudinal comparative histometric study of the biocompatibility of three local hemostatic agents. Int J Oral Maxillofac Surg 1990;19(1):47-50.

14. Matthew IR, Browne RM, Frame JW, Millar $B G$. Tissue response to a haemostatic alginate wound dressing in tooth extraction sockets. Br J Oral Maxillofac Surg 1993;31(3): 165-9.

15. Goker H, Haznedaroglu IC, Ercetin S, Kirazli S, Akman U, Ozturk Y, et al. Haemostatic actions of the folkloric medicinal plant extract Ankaferd Blood Stopper. J Int Med Res 2008; 36(1):163-70.

16. Al B, Yildirim C, Cavdar $M$, Zengin $S$, Buyukaslan $\mathrm{H}$, Kalender ME. Effectiveness of Ankaferd blood stopper in the topical control of active bleeding due to cutaneous-subcutaneous incisions. Saudi Med J 2009;30(12): 1520-5.

17. Teker AM, Korkut AY, Gedikli O, Kahya V. Prospective, controlled clinical trial of Ankaferd Blood Stopper in children undergoing tonsillectomy. Int J Pediatr Otorhinolaryngol 2009; 73(12):1742-5.

18. Leblebisatan G, Bay A, Karakus SC, Kekilli M, Haznedaroglu IC. Topical Ankaferd hemostat application for the management of oral cavity bleedings in children with hemorrhagic diathesis. Blood Coagul Fibrinolysis 2012;23(6): 494-7.

19. Beyazit $Y$, Kart $T$, Kuscu A, Arslan A, Kurt M, Aktas $B$, et al. Successful management of bleeding after dental procedures with application of blood stopper: a single center prospective trial. J Contemp Dent Pract 2011;12(5): 379-84.

20. Cipil HS, Kosar A, Kaya A, Uz B, Haznedaroglu IC, Goker $\mathrm{H}$, et al. In vivo hemostatic effect of the medicinal plant extract Ankaferd Blood Stopper in rats pretreated with warfarin. Clin Appl Thromb Hemost 2009; 15(3):270-6.

21. Kosar A, Cipil HS, Kaya A, Uz B, Haznedaroglu IC, Goker H, et al. The efficacy of Ankaferd Blood Stopper in antithrombotic drug-induced primary and secondary hemostatic abnormalities of a rat-bleeding model. Blood Coagul Fibrinolysis 2009;20(3):185-90.

22. Akkoç N, Akçelik M, Haznedaroğlu iC, Göker $\mathrm{H}$, Turgut M, Aksu S, et al. In vitro anti-bacterial activities of Ankaferd medicinal plant extract. Turkiye Klinikleri J Med Sci 2009;29(2): 410-5.

23. Gül Ş, Bahadır B, Kalaycı M, Ankaralı H, Erdem O, Karakaya K, et al. Effects of Ankaferd Blood Stopper (R) on bone regeneration in rat calvarial defects. Turkiye Klinikleri J Med Sci 2011;31(2):390-6.

24. Uğur $Y$, Sari $O$, Uğur $O$, Korkusuz $P$, Varoğlu $\mathrm{E}$, Arslan N, et al. Lack of correlation between Tc-99m-sestaMIBI uptake and cadherin expression in infiltrating ductal breast carcinoma as prognostic indicators. Ann Nucl Med 2003; 17(4):281-7.

25. Dogru MT, Aydos TR, Aktuna Z, Korkusuz P, Zeybek D, Görgü N, et al. The effects of betablockers on endothelial nitric oxide synthase immunoreactivity in the rat corpus cavernosum. Urology 2010;75(3):589-97.

26. Eming SA, Brachvogel B, Odorisio T, Koch M. Regulation of angiogenesis: wound healing as a model. Prog Histochem Cytochem 2007; 42(3):115-70.

27. Aukhil I. Biology of wound healing. Periodontol 2000 2000;22:44-50.

28. Hinz B. Formation and function of the myofibroblast during tissue repair. J Invest Dermatol 2007;127(3):526-37.

29. Gabbiani G. The biology of the myofibroblast. Kidney Int 1992;41(3):530-2.

30. Gabbiani G. Evolution and clinical implications of the myofibroblast concept. Cardiovasc Res 1998;38(3):545-8.

31. Tomasek JJ, Gabbiani G, Hinz B, Chaponnier C, Brown RA. Myofibroblasts and mechanoregulation of connective tissue remodelling. Nat Rev Mol Cell Biol 2002;3(5):349-63.

32. Li B, Wang JH. Fibroblasts and myofibroblasts in wound healing: force generation and measurement. J Tissue Viability 2011;20(4):108-20.

33. Valenick LV, Hsia HC, Schwarzbauer JE. Fibronectin fragmentation promotes alpha4 beta1 integrin-mediated contraction of a fibrin- fibronectin provisional matrix. Exp Cell Res 2005;309(1):48-55.

34. Colvin R. Fibronectin in Wound Healing. In: Mosher D, ed. Biology of Extracelluler Matrix: A Series Fibronectin. New York: Academic Press; 1989. p. 213-54.

35. Yamada KM, Clark RAF. Provisional matrix. In: Clark RAF, ed. The Molecular and Cellular Biology of Wound Repair. $2^{\text {nd }}$ ed. New York: Plenum Press; 1996. p.51-93.

36. Hynes RO. Fibronectins. $1^{\text {st }}$ ed. New York: Springer-Verlang; 1990. p.1-571.

37. Ferrara N. Vascular endothelial growth factor as a target for anticancer therapy. Oncologist 2004;9(Suppl 1):2-10.

38. Rossiter H, Barresi C, Pammer J, Rendl M, Haigh J, Wagner EF, et al. Loss of vascular endothelial growth factor a activity in murine epidermal keratinocytes delays wound healing and inhibits tumor formation. Cancer Res 2004;64(10):3508-16.

39. Galiano RD, Tepper OM, Pelo CR, Bhatt KA, Callaghan M, Bastidas N, et al. Topical vascular endothelial growth factor accelerates diabetic wound healing through increased angiogenesis and by mobilizing and recruiting bone marrow-derived cells. Am J Pathol 2004;164(6):1935-47.

40. Ploegh HL, Orr HT, Strominger JL. Major histocompatibility antigens: the human (HLA-A, $-\mathrm{B},-\mathrm{C})$ and murine (H-2K, $\mathrm{H}-2 \mathrm{D})$ class I molecules. Cell 1981;24(2):287-99.

41. Danon D, Kowatch MA, Roth GS. Promotion of wound repair in old mice by local injection of macrophages. Proc Natl Acad Sci U S A 1989; 86(6):2018-20.

42. Browder W, Williams D, Lucore $P$, Pretus $H$, Jones $E$, McNamee R. Effect of enhanced macrophage function on early wound healing. Surgery 1988;104(2):224-30.

43. Guo $S$, Dipietro LA. Factors affecting wound healing. J Dent Res 2010;89(3):219-29.

44. Isakson P. Pharmacology of Cox-2 inhibitors. In: Dannenberg AJ, DuBois RN, eds. Cox-2 A New Target for Cancer Prevention and Treatment. $1^{\text {st }}$ ed. Basel: Karger; 2003. p. 2551.

45. Calanni F, Laufer S. Biochemistry and mediators of inflammation. In: Laufer S, Gay S, Brune K, eds. Inflammation and Rheumatic Diseases. $1^{\text {st }}$ ed. Stuttgart: Thieme; 2003. p.15-52.

46. Muscará MN, McKnight W, Asfaha S, Wallace JL. Wound collagen deposition in rats: effects of an NO-NSAID and a selective COX-2 inhibitor. Br J Pharmacol 2000;129(4):681-6.

47. Simon AM, Manigrasso MB, O'Connor JP. Cyclo-oxygenase 2 function is essential for bone fracture healing. J Bone Miner Res 2002; 17(6):963-76. 